УДК 811.161.2'36

DOI https://doi.org/10.26661/2414-1135-2021-82-29

\title{
ДОСЛІДЖЕННЯ ІМЕННИКА ТА ЙОГО МОРФОЛОГІЧНИХ КАТЕГОРІЙ ІЗ ПОГЛЯДУ СЕМАНТИКО-ГРАМАТИЧНОЇ АСИМЕТРІЇ
}

\author{
Мороз Т. Ю. \\ кандидат філологічних наук, доиент, \\ дочент кафедри іноземних мов № 1 \\ Національний юридччний університет імені Ярослава Мудрого \\ вул. Пушкінська, 77, Харків, Україна \\ orcid.org/0000-0001-6153-8136 \\ t.moroz0904@gmail.com
}

Ключові слова: асиметричні вияви, загальнокатегорійне значення предметності, категорія числа, роду, істоти/неістоти.
Дослідження семантико-граматичної асиметрії у сфері морфологічних категорій іменника як одного з різновидів явища асиметрії, що характеризує будь-яку природну мову на всіх рівнях іiі організації (структури й системи) i функціонування, передбачає чітке визначення термінів, за допомогою яких здійснюється опис відповідного явища. Статтю присвячено окресленню стратегії дослідження морфологічних категорій іменника в аспекті семантико-граматичної асиметрії, аналізу термінів і понять морфологічної теорії, значущих для вивчення проблеми семантико-граматичної асиметрії на рівні морфологічних категорій іменника.

Для здійснення аналізу явища семантико-граматичної асиметрії у сфері морфологічних категорій іменника автор дослідила й окреслила позиції та погляди мовознавців на проблему кількості й характеру субстантивних морфологічних категорій, їх співвідношення із загальнокатегорійним значенням імені, схарактеризувала роль загальнокатегорійного значення предметності й морфологічних категорій у класифікаційному виділенні іменника.

Акцент саме на морфологічні категорії іменника зумовив аналіз традиційних і сучасних поглядів на систему субстантивних граматичних категорій, що уможливило визнати власне морфологічними такі категорії, як число, рід та істоту.

Граматична категорія відмінка іменників свідомо вилучена зі сфери аналізу в аспекті семантико-граматичної асиметрії. Це зумовлено існуванням суперечливих поглядів на цю категорію в наукових колах i складністю самої категорії для такого аналізу. У межах категорії відмінка взаємодіють семантичні, морфологічні й синтаксичні чинники з виразним домінуванням синтаксичних, що дає вагомі підстави для кваліфікації відмінка не тільки як граматичної, а й синтаксичної категорії.

Системність морфологічних категорій іменника визначається існуванням між ними ієрархічної співвіднесеності та рівнорядної взаємодії, які в результаті забезпечують i формують граматичну характеристику іменників першого рівня абстракції - категорії предметності, яка й конституює іменник як частину мову. 


\title{
THE STUDY OF THE NOUN AND ITS MORPHOLOGICAL CATEGORIES IN TERMS OF SEMANTIC-GRAMMATICAL ASYMMETRY
}

\author{
Moroz T. Yu. \\ PhD in Linguistics, Associate Professor, \\ Associate Professor at the Foreign Languages Department № 1 \\ Yaroslav Mudryi National Law University \\ Pushkinska str., 77, Kharkiv, Ukraine \\ orcid.org/0000-0001-6153-8136 \\ t.moroz0904@gmail.com
}

Key words: asymmetric phenomena, general categorical meaning of subjectivity, category of number, category of gender, category of animation/ inanimation.
The study of semantic-grammatical asymmetry in the field of morphological categories of the noun as one of the types of asymmetry, which characterizes any natural language at all levels of its organization (structure and system) and functioning, provides a clear definition of terms used to describe the phenomenon. The article is devoted to outlining the strategy of research of morphological categories of noun in the aspect of semantic-grammatical asymmetry, analysis of terms and concepts of morphological theory, significant for studying the problem of semantic-grammatical asymmetry at the level of morphological categories of noun.

To analyze the phenomenon of semantic-grammatical asymmetry in the field of morphological categories of noun, the author researched and outlined the positions and views of linguists on the number and nature of substantive morphological categories, their relationship with the general categorical meaning of the name, characterized the role of general categorical meaning of subjectivity and morphological categories in the classification of a noun.

The emphasis on the morphological categories of the noun led to the analysis of traditional and modern views on the system of substantive grammatical categories, which enables to recognize such categories as number, gender and animation as proper-morphological.

The grammatical category of the case of nouns is deliberately removed from the sphere of analysis in the aspect of semantic-grammatical asymmetry. This is caused by the existence of contradictory views on this category in scientific circles and the complexity of the category itself for such an analysis. Within the category of the case, semantic, morphological and syntactic factors interact with a clear dominance of syntactic ones, which gives good grounds for qualifying the case not only as a grammatical but a syntactic category.

The systemic nature of morphological categories of the noun is determined by the existence of hierarchical correlation and equal interaction between them, which as a result provide and form a grammatical characteristic of nouns of the first level of abstraction - the category of subjectivity, which constitutes the noun as a part of speech.
Постановка проблеми. Іменник (ім'я) поряд із дієсловом (предикат) становлять ядерні групування слів у багатьох мовах. Проте саме іменник найбільш чітко виділяється в мовах світу [1, с. 45], пояснення чого дослідники вбачають в особливостях сприйняття людським мисленням світу. Саме іменник ще 3 давніх часів був об'єктом пильної уваги науковців.

Сьогодні існує значний корпус досліджень, присвячених проблемі іменника та його категорій. Вітчизняне мовознавство в цьому плані також має значні здобутки. 3-поміж дослідників, що зробили помітний внесок до вивчення специфіки іменника, його семантичних, словотвірних, граматичних особливостей, варто згадати І.К. Білодіда, О.О. Потебню, Л.І. Булаховського, К.Г. Городенську, I.І. Ковалика, І.Г. Матвіяса, В.С. Ільїна, I.P. Вихованця, О.К. Безпояско, А.П. Загнітка, В.М. Русанівського, Н.Г. Озерову, О.О. Колесникова, О.А. Олексенко й ін.

У загальних рисах окреслюючи сучасний погляд на іменник, передусім варто зазначити, що 
слова цього класу розглядаються як такі, що формують одну 3 ядерних частин мови, протиставлену за своїми ономасіологічними та семасіологічними ознаками дієслову.

3 ономасіологічного погляду ознакою, яка кардинально протиставляє слова іменникового класу всім іншим угрупованням, науковцями визнається узагальнене граматичне значення предметності, або загальнокатегорійне значення предметності.

Мета й завдання статті. Для здійснення аналізу явища семантико-граматичної асиметрії у сфері морфологічних категорій іменника необхідно дослідити й окреслити позиції та погляди мовознавців на проблему кількості й характеру субстантивних морфологічних категорій, їх співвідношення із загальнокатегорійним значенням імені, схарактеризувати роль загальнокатегорійного значення предметності та морфологічних категорій у класифікаційному виділенні іменника.

Предмет та об’скт дослідження. Адекватне дослідження семантико-граматичної асиметрії у сфері морфологічних категорій іменника як одного 3 різновидів явища асиметрії, що характеризує будь-яку природну мову на всіх рівнях їі організації (структури й системи) i функціонування, передбачає передусім чітке визначення термінів, за допомогою яких здійснюється опис відповідного явища. Тому статтю присвячено окресленню стратегії дослідження морфологічних категорій іменника в аспекті семантико-граматичної асиметрії, аналізу термінів і понять морфологічної теорії, значущих для вивчення проблеми семантико-граматичної асиметрії на рівні морфологічних категорій іменника.

Виклад основного матеріалу дослідження. Розглянемо питання про предметність як основну ономасіологічну ознаку іменників. Полишаючи осторонь проблему, співвідношення узагальненого граматичного значення та часткових граматичних значень, обговорення якої було й залишається актуальним для сучасної лінгвістики [2, с. 22-34], варто лише зазначити, що загалом це співвідношення мислиться дослідниками так: «Граматичні значення розвивають і конкретизують зазвичай ту загальну ідею, яка закладена в загальнокатегорійній семантиці окремих частин мови... Граматичні значення існують як віддзеркалювачі можливої класифікації й рубрикації одного загальнокатегорійного значення, це смислові варіанти одного інваріанта. Граматичні значення - це своєрідні «підзначення» категорій предметності, процесності й атрибутивності. Це рубрики класифікації всередині частин мови, яка існує безвідносно до значення інших представлених у мові частин мови» [1, с. 77].

Отже, предметність - це загальнокатегорійне значення (семантика), яке об'єднує лексеми із цією характеристикою в один клас (частину мови) - іменників, а граматичні категорії, які характеризують цей клас, слугують засобом відображення цього значення. При цьому неоднорідність утілення загальнокатегорійного значення в словах цього класу виявляється саме в тому, що для одних із них питомими є всі часткові граматичні значення в повному обсязі, для інших також характерні всі граматичні характеристики, але 3 певними обмеженнями.

За своїм складом, відповідно до глибинної семантичної характеристики (предметності), іменникова лексика не становить однорідного утворення, формуючись із ядра та периферії. До семантично ядерних іменників належать назви конкретних предметів і понять, які $\epsilon$ непредикатними, первинними іменами. Цю групу імен конституює семантика власне-предметності. Периферію іменників становлять предикатні, вторинні, імена, глибинна семантика яких репрезентована невласне-предметністю (опредмеченими ознаками, діями, ознаками ознак), які однак на рівні граматичної семантики (поверхневої) також фігурують як носії семантики предметності [1, с. $45 ; 3$, с. $135 ;$ 4, с. 45-49]. I.Р. Вихованець так резюмує співвідношення первинних і вторинних іменників: «Будь-які вторинні іменники, що являють собою семантично похідні одиниці від дієслова, прикметника і прислівника, з одного боку, і від цілого висловлювання або ряду висловлювань, з іншого боку, у формально-синтаксичному, семантико-синтаксичному й морфологічному планах завжди грунтуються на первинних іменниках $\mathrm{i}$ внаслідок цього набувають граматичної предметності» [4, с. 49]. Варто зазначити, що така позиція вже давно висловлювалася в мовознавчих працях. Для порівняння можна навести думку О.М. Галкіної-Федорук, яка в дещо іншій термінології формулює подібну позицію: «Якщо взяти ряд слів: дім, біганина, смуток, радість, краса, твердість, то ми бачимо, - пише дослідниця, - що вони позначають різне: дім - предмет, біганина - процес, смуток - якість, радість - почуття, краса якість, твердість - властивість. Але граматичне узагальнення знімає різницю понять, і всі зазначені слова й подібні до них підводяться під один граматичний ряд - іменник» [5, с. 380].

Особливе місце в класі іменників поряд із первинними та вторинними займають загалом семантично спустошені слова, які при цьому, однак, несуть у собі головне загальнокатегорійне значення предметності, - займенникові іменники.

У сьогоднішньому мовознавстві вже загальноприйнятою позицією $є$ погляд на займенник не як на окрему частину мови, а як на специфічні займенникові слова, які маючи певну специфіку, пов' язану передусім зі способом позначення ними 
реалій позамовної дійсності, за своїми граматичними ознаками все ж мають бути зараховувані до інших частин мови. Відтак із-посеред займенникових слів виокремлюються слова, які прийнято називати займенниковими іменниками, займенниковими прикметниками, займенниковими числівниками та займенниковими прислівниками. Цей підхід чітко окреслений у низці праць із питань морфології [4; 6, с. 302-308]. Однак у деяких наукових джерелах усе ж статус займенників визначено через констатацію їх частиномовного статусу. Так, I.P. Вихованець, даючи визначення займенника, зазначав таке: «Займенник - частина мови, що вказує на особу, предмет або ознаку, але не називає їх. Займенники утворюють особливу систему слів-субститутів (слів-замінників), які, крім того, виявляють значеннєву, морфологічну i синтаксичну спільність із відповідними частинами мови» [7, с. 173]. Водночас, відповідно до останнього положення, дослідник зауважує, що сьогодні існує дві найбільш поширені теорії щодо статусу займенників: розуміння займенника як окремої частини мови, з одного боку, і невизнання самостійного частиномовного статусу займенників - з іншого [7, с. 174].

Ми підтримуємо погляд, згідно з яким займенникові слова не становлять окремої частини мови, що закономірно передбачає необхідність дослідження займенникових іменників нарівні з власне іменниками в аспекті семантико-граматичної асиметрії, що притаманна їм у сфері морфологічних категорій. Однак урахування того факту, що займенникові іменники за специфікою вираження значення предметності загалом і граматичних значень, що його конституюють і деталізують (значення числа, роду, істоти/неістоти, відмінка), можуть бути поставлені в один ряд із власне іменниками, дає змогу відмовитися від спеціального розгляду їх специфіки в аспекті семантико-граматичної асиметрії на рівні морфологічних категоpiй. Доречно при цьому наголосити, що глибокий i всебічний аналіз специфіки вираження займенниковими іменниками граматичних значень порівняно 3 власне іменниками вже запропонований [2; 4, с. 184-202; 9; 18]. Окремо варто зауважити, що саме займенниковим іменникам належить першість у реалізації граматичного категорійного значення особи/неособи.

Підсумовуючи розгляд питання про предметність як основну ономасіологічну ознаку іменників і транспонуючи це питання на проблему асиметрії, варто сказати, що саме глибинна семантика власне предметності конкретних іменників (дім, стіл), яка здатна втілюватися у відповідній кількості морфологічних категорій із певними якісними характеристиками, становить фрагмент, який може бути означений як симетричний.
Саме на рівні цієї лексики може бути визначене ідеальне співвідношення значення i форми, семантики і граматики у сфері іменникової лексики. Шляхом семантичного зараження первинні іменники впливають на вторинні іменники, унаслідок чого ті набувають семантики предметності (невласне-предметності). Однак саме через свою невласне предметність останні не здатні переймати весь діапазон формальних ознак у сфері реалізації морфологічних значень, що досить часто й визначає їх статус як системно асиметричних, тобто як таких, що характеризуються неповним набором граматичних ознак, які типові для первинних іменників.

Загальнокатегорійне значення предметності, яке консолідує клас іменників, реалізується на рівні більш часткових значень - лексичних (семантичних) і граматичних, крім цього, забезпечуючись спеціальними словотвірними засобами та характеризуючись специфічною синтаксичною функціональністю. Відповідно до цього, у лінгвістиці прийнято говорити про те, що предметність охоплює кілька семантичних і граматичних категорій, конкретніших і вужчих, ніж категоріальне [10, с. 24]. При цьому «морфологічним категоріям належить провідна роль у класифікаційному виділенні іменника, проте виражаються вони з різним ступенем послідовності щодо окремих груп лексичних одиниць, які виділяються за більш конкретними семантичними ознаками в межах загальнокатегоріального значення предметності» [11, с. 40]. Іншими словами, значення предметності реалізується шляхом тісної взаємодії конкретнішої семантики лексичних одиниць i більш узагальненої граматичної семантики, причому граматична (морфологічна) семантика, маючи більшу виражальну силу щодо предметності, водночас перебуває під впливом лексичної семантики, зумовлена іiі специфікою. Необхідно зазначити, що семантико-граматична асиметрія на рівні морфологічних категорій іменника передусім зумовлена саме активною дією лексичної семантики.

На підставі взаємодії лексичного та граматичного в слові прийнято членувати увесь клас іменникових лексем на певні лексико-граматичні розряди. Цей поділ, як відомо, здійснюється в основному на підставі семантичної специфіки іменників у іiі стосунку до граматики, хоча не залишається поза увагою й те, що ця специфіка має певні наслідки на рівні формального вираження. Так, А.П. Загнітко зауважує: «Термінологічне окреслення слів як лексико-граматичного розряду є ємнішим і передбачає: 1) об'єднання слів на грунті семантичної спільності; 2) значущість угруповання для граматики; 3) морфемну маркованість/немаркованість» [2, с. 35]. 
За семантичною специфікою іменників у іiі стосунку до домінантного загального значення предметності, реалізовуваного передусім граматичними (морфологічними) категоріями, що охоплюють усю сукупність класу іменників, субстантиви більшістю дослідників традиційно розподіляються на такі лексико-граматичні розряди: 1) власні - загальні; 2) предметні (дискретні, раховані) - речовинні (недискретні, нераховані); 3) конкретні - абстрактні; 4) збірні - одиничні. Можливий і інший розподіл і співвідношення зазначених груп. Так, наприклад, І.Р. Вихованець і К.Г. Городенська іменникову лексику на лексико-граматичні розряди розподіляють у такий спосіб: 1) іменники власні й загальні; іменники конкретні й абстрактні; 3) іменники збірні й речовинні [4, с. 50]. Як для одного, так і для іншого варіантів групування й протиставлення є свої підстави. Щоправда, при цьому не можна не враховувати суттєву заувагу О.О. Колесникова, який спостеріг, що загалом розподіл на лексико-граматичні розряди здійснюється в межах опозицій, натомість виділення збірних іменників нібито не має належного протиставлення. Це, на його думку, є свідченням і переконливим доказом того, що вичленування збірних іменників як лексико-граматичного розряду $є$ хибним. У зв'язку з цим дослідник пропонує розглядати збірність як вияв третьої грамеми на рівні категорії числа [3]. Аналіз цієї позиції буде здійснено в розділі, присвяченому категорії числа. Тут лише варто зауважити, що в роботі підтримано погляд, згідно 3 яким збірні іменники $є$ лексико-граматичним розрядом, характер специфічного стосунку якого до категорії числа зумовлений прагматичними чинниками, що загалом відповідає концепції, розробленій Д.І. Руденком [12].

Водночас у деяких дослідженнях запропонований поділ на лексико-граматичні розряди (у тому або тому співвідношенні цих розрядів) доповнюється також такими розрядами, як особа/неособа, істота/неістота [14 10]. У пропонованому дослідженні за вихідну взято підтримувану багатьма сучасними дослідниками позицію, відповідно до якої протиставлення особи/неособи та істоти/ неістоти $є$ передусім граматичними категоріями, які перебувають на периферії категорійної системи іменника [2, с. 54-59].

3 методологічних міркувань доцільно більш детально визначитися зі специфікою наведеного групування й обсягом лексики, яка підпадає під той чи інший розряд. При цьому спеціально не зауважується (як факт загальновідомий), що між розрядами лексики існує ціла мережа взаємоперехрещень і взаємовпливів і постійно відбуваються процеси взаємопереходів.

Уся іменникова лексика поділяється на іменники власні й загальні, або загальні назви (апе- лятиви) та власні назви (оніми). Власні назви становлять значний прошарок лексики, у якому розрізняють декілька класів назв, зокрема антропоніми, топоніми, космоніми, теоніми, міфоніми, зооніми, ергоніми, хрематоніми тощо. Загалом, за спостереженнями дослідників, кількість власних назв рахується мільйонами, що значно більше, ніж загальних назв, однак у мовному запасі окремої людини онімів набагато менше, ніж апелятивів, що призводить до хибного уявлення про порівняно меншу кількість саме онімів. Однак кількісні параметри співвідношення онімів/апелятивів усе ж не $\epsilon$ визначальними, що закономірно дає дослідникам підстави висновувати, що «загальні назви $\epsilon$, безперечно, центральним шаром лексики, а власні назви становлять її потужну периферію 3 дуже різною сферою поширення» [7,c. 80].

Основними ознаками, що різнять власні назви від загальних, є: 1) належність одиниці; 2) специфічне відношення до поняття (власна назва подає всю інформацію про свій денотат без певних узагальнень і тому пов'язується 3 поняттями лише тією мірою, якою вказує на різновид об'єктів, до яких належить денотат); 3) специфічна функція, а саме функція диференціації; тощо [7, с. 79].

Зазначені характеристики власних назв на рівні лексичної системи мають вагоме значення й для 3'ясування особливостей поведінки онімів на рівні граматичної системи, зокрема в системі морфологічних категорій іменника. При цьому варто зазначити, що найбільш специфічною є поведінка іменників - власних назв щодо категорії числа, тобто у сфері вираження ними числових значень.

Назагал, визначаючи статус власних назв в іменниковій системі в термінах ядра/периферії як однієї з форм вияву асиметрії в мові, необхідно його означити як периферійний, тобто асиметричний. Це, з одного боку, зумовлено тим, що власні назви $є$ периферійними як складник лексичної системи, а з іншого - тим, що вони характеризуються специфічними ознаками, які, у свою чергу, визначають їх особливу поведінку у сфері морфологічних категорій. Саме у зв'язку з цим для іменників - власних назв надзвичайно характерна асиметрія між семантикою та граматикою [13, c. 112-117].

На інших порівняно 3 поділом на власні й загальні назви підставах здійснюється поділ іменників на розряди конкретних та абстрактних, а саме на грунті позначення тими чи іншими іменниками об'єктів реальності, що сприймаються людськими органами чуття, або таких об’єктів, що не існують у реальності, а $є$ результатом абстрагуючої діяльності людського мислення.

До конкретних іменників належать назви, що позначають дискретні предмети, тобто ті, що виокремлюються людською свідомістю як 
просторово чітко дислоковані, а відтак можуть бути піддані процедурі рахування. Саме ці іменники найбільшою мірою $\epsilon$ репрезентантами загальнокатегорійного значення предметності, тобто первинними іменника. 3 огляду на це на їх рівні вдається спостерігати найбільш послідовну реалізацію всіх частково категорійних морфологічних значень, що характерні іменникові. Специфічну групу, щоправда, в межах цього розряду становлять іменники формального класу pluralia tantum на зразок сани, окуляри, кішки, які, утілюючи семантику власне предметності, характеризуються особливим відношенням до категорії числа, а відтак і до категорії роду.

Розряд абстрактних іменників формується сукупністю декількох груп, виділених відповідно до того, що абстрагується - ознака, дія, процес, стан тощо. Семантичною сутністю цього розряду $є$ те, що в «шати» предметності втілюються непредметні значення. Ця операція стає можливою внаслідок абстрагувальної діяльності людської свідомості, яка може нематеріальні, недискретні, тобто нелокалізовані в часі й просторі, ознаки, дії тощо «відривати» від їх предметних носіїв і представляти як предметні реалії. Оскільки процедурі абстрагування піддаються дії, стани, ознаки тощо, то цілком закономірно, що більшість абстрактних іменників $€$ похідними, вторинними іменниками, утвореними від дієслів, прикметників тощо найчастіше за допомогою відповідних словотвірних засобів.

Під поняття «абстрактні іменники» зараховуються назви дій, процесів, станів, якостей, властивостей, одиниць міри й ваги, наукові поняття тощо. При цьому не викликає заперечень прийнята в лінгвістиці позиція, що диференційною ознакою цих іменників є неповнота числової парадигми: вони належать або лише до однини, або лише до множини, хоча за певних умов (контекстних, через розвиток лексичного значення) можуть порушувати цю закономірність [4, с. 52; 10, с. 31-32].

Виділення розрядів одиничних, збірних і речовинних іменників у науковій літературі характеризується найбільшою суперечливістю. Так, розряд речовинних іменників виділяється на основі того, що ними позначаються недискретні, тобто які не мають чіткої просторової локалізованості, не придатні до виділення, предметні сутності, які не можна порахувати, а можна лише виміряти, зважити тощо. За цією ознакою речовинні протистоять конкретним предметним іменникам, водночас зближаючись зі збірними, для яких недискретність, нерозчленованість також є провідною семантичною характеристикою. У зв'язку з цим цілком виправданою є заувага М.В. Леонової, що речовинні іменники називають особливу форму збірності [10, с. 33].
У межах цього розряду прийнято виділяти назви: 1) металів; 2) хімічних елементів; 3) ліків і препаратів; 4) рідин; 5) тканин; 6) злаків і трав; 7) рослин; 8) ягід і овочів; 9) різних матеріалів; 10) продуктів харчування; 11) природних явищ тощо. 3 огляду на специфічну лексичну семантику, слова цього розряду характеризуються своєрідним відношенням до граматичної категорії числа: більшість із них мають лише форму однини й лише незначна частина має лише множину. Утворення корелятів - форм множини від однини, яке інколи спостерігається, є цілком закономірним і зумовлене, за спостереженнями дослідників, зміною в лексичному значенні вихідних слів [4, с. 53; 10, с. 33].

Виділення такого розряду іменників, як одиничні, або сингулятиви, зумовлене тим, що від іменників речовинної семантики за допомогою певних словотвірних засобів можуть утворюватися іменники на позначення частини певної маси (речовини), наприклад: солома - соломина, бадилля - бадилина, борошно - борошнина. Цей розряд іменникової лексики вважають одним із тих, що може бути означений як ядерний у ряду характеризованих (у термінології О.В. Бондарка) розрядів, оскільки має послідовне формальне забезпечення [2, с. 36]. Щоправда, логічність виділення цього розряду саме як лексико-граматичного досить сумнівна, оскільки форми одиничних іменників у граматичному плані характеризуються цілком типовою для власне предметних іменників семантикою та формою іï вираження, утворюючи навіть корелятивні форми однини та множини, пор.: соломина - соломини.

Іменники розряду збірних становлять найсуперечливіший фрагмент щодо свого статусу, обсягу, граматичної специфіки. Що стосується статусу, то, як уже зазначалося, одні вважають такі іменники лексико-граматичним розрядом (О.В. Бондарко, А.П. Загнітко, К.Г. Городенська, О.К. Безпояско та iн.), інші - грамемою категорії числа (О.О. Колесников), треті - семантичним групуванням у межах абстрактних іменників (О.П. Мосьпан). Не існує усталеності й щодо обсягу (якості) іменників, які мають бути зараховувані до збірних [14; 3].

Згідно 3 найбільш поширеним поглядом на іменники збірної семантики, збірні іменники мають значення нерозчленованої сукупності однорідних предметів, репрезентованої як цілісність, і становлять лексико-семантичний розряд, оскільки характеризуються спільним у граматичному плані, а саме існують лише у формі однини. При цьому обсяг цього розряду визначається значною мірою наявністю словотвірних засобів вираження збірності в морфемній структурі іменника. До цих засобів належать суфікси: $\mathrm{cms-}$ (селянство), -j- (пір'я, бадилля), -н'- (комашня), -в- (мишва), -ин':- (гарбузиння), -ин- (городина), 
-ник (сливник), -няк (лозняк, молодняк), -от(парубота), -еч- (малеча), -изн- (білизна), -ар(мошкара), -ор- (дітвора), -ур- (апаратура), -ат (єпископат), -атик- (проблематика), -іан- (Шевченкіана) (хоча, наприклад, А.П. Загнітко відносить іменники цього словотвірного типу до абстрактних [2, с. 38]), -i- (омонімія), -арій (гербарій). Крім цього, невелику частину становлять безсуфіксні іменники, наприклад: юнь, зелень, молодь, нечисть, знать, хвоя. Аналіз іменників цього розряду здійснюється 3 урахуванням висловлюваного в лінгвістичній науці міркування про збірність як специфічну групу лексем, об'єднувану на підставі важливої ролі в їх виникненні та функціонуванні прагматичних чинників [14].

Відповідно до загальноприйнятого погляду, не зараховуються до лексико-граматичного розряду збірних іменники, які, утілюючи семантику збірності, тобто належачи загалом до функціонально-семантичного поля збірності, не характеризуються специфічним відношенням до категорії числа. До таких іменників належать лексеми на зразок полк, народ, колектив, оркестр, ансамбль, плем'я тощо. Як зазначають дослідники, для цих іменників характерна наявність семи «розчленована сукупність», що сприяє їх здатності утворювати корелятивні форми числа, пор.: полк-полки, плем'я-племена [15, с. 46].

Наведений вище розподіл іменникової лексики на лексико-граматичні розряди, як засвідчує запропонований опис та аналіз джерел із питання, значною мірою здійснений на підставі характеру взаємодії лексичної семантики тієї чи іншої лексеми певного розряду з морфологічною категорією числа $[4$, с. 50-53; 11 , с. 40-46], що зайвий раз підтверджує слушність думки дослідників про морфологічну категорію числа як основну в категорійній ієрархії іменника.

Висновки й перспективи подальших розробок. Науково обгрунтоване дослідження семантико-граматичної асиметрії неможливе без чіткого визначення термінів і понять, за допомогою яких здійснюється опис відповідного явища. Акцент саме на морфологічні категорії іменника зумовив аналіз традиційних і сучасних поглядів на систему субстантивних граматичних категорій, що уможливило визнати власне-морфологічними такі категорії, як число, рід та істота.

Зі сфери аналізу в аспекті семантико-граматичної асиметрії свідомо вилучено граматичну категорію відмінка іменників, що зумовлено, з одного боку, існуванням суперечливих поглядів на цю категорію в наукових колах, а 3 іншого - складністю самої категорії для такого аналізу, у межах якої тісно взаємодіють семантичні, морфологічні та синтаксичні чинники з виразним домінуванням останніх, що дає вагомі підстави для кваліфікації відмінка не тільки як граматичної, а й синтаксичної категорії.

Системність морфологічних категорій іменника визначається існуванням між ними ієрархічної співвіднесеності та рівнорядної взаємодії, які в результаті забезпечують і формують граматичну характеристику іменників першого рівня абстракції - категорії предметності, яка й конституює іменник як частину мову.

Найпоказовішими для 3'ясування виявів i характеру семантико-граматичної асиметрії є три морфологічні категорії іменника: числа, істоти/ неістоти й роду.

\section{ЛІТЕРАТУРА}

1. Кубрякова Е.С. Части речи в ономасиологическом освещении / АН СССР. Институт языкознания. Москва : Наука, 1978. 115 с.

2. Загнітко А.П. Теоретична граматика української мови: Морфологія : монографія. Донецьк : ДонДУ, 1996. 437 с.

3. Колесников А.О. Синтагматична парадигматика категорії числа морфологічно недостатніх іменників : автореф. дис. ... канд. філол. наук / Одеський нац. ун-т ім. I.I. Мечникова. Одеса, 2000. 19 с.

4. Вихованець I.P. Теоретична морфологія української мови: Академ. граматика укр. мови / за ред. І. Вихованця. Київ : Унів. вид-во «Пульсари», 2004. 400 с.

5. Галкина-Федорук Е.М. О форме и содержании в языке. Мышление и язык / под ред. Д.П. Горского. АН СРСР. Ин-т философии. Москва : Гос. изд-во полит. лит-ры, 1957. С. 352-407.

6. Милославский И.Г. Морфологические категории современного русского языка : учебное пособие по спецкурсу для студентов пед. ин-тов по спец. № 2101 «Рус. яз. и лит.». Москва : Просвещение, 1981. 254 с.

7. Українська мова: Енциклопедія / редкол.: В.М. Русанівський, О.О. Тараненко (співголови), М.П. Зяблюк та ін. Київ : Вид-во «Укр. енцикл.» ім. М.П. Бажана, 2000. 752 с.

8. Ожоган B.M. Займенникові слова у граматичній структурі сучасної української мови. Київ : Б.в., 1997. 230 с.

9. Матвіяс І.Г. Синтаксис займенників в українській мові. Київ : Вид-во АН УРСР, 1962. 131 с.

10. Леонова М.В. Сучасна українська літературна мова. Морфологія. Київ : Вища шк., 1983. $264 \mathrm{c}$.

11. Украинская грамматика / В.М. Русановский, М.А. Жовтобрюх, Е.Г. Городенская, А.А. Грищенко. АН УССР. Ин-т языковедения им. А.А. Потебни. Київ : Наук. думка, 1986.

12. Руденко Д.И. Категория имени в основных парадигмах «философии языка» : авто- 
реф. дисс. ... докт. филол. наук / АН СССР. Ин-т языкознания. Москва, 1990. 63 с.

13. Суперанская А.В. Апеллятив - онома. Имя нарицательное и собственное / отв. ред. докт. филол. наук А.В. Суперанская. АН СССР. Ин-т языкознания. Москва : Наука, 1978. С. 5-34.

14. Мосьпан О.П. Поле збірних іменників у російській мові: особливості семантики та прагматики : автореф. дис. ... канд. філол. наук / Харківський нац. ун-т ім. В.Н. Каразіна. Харків, 2000.

15. Горпинич В.О. Морфологія української мови : рідручник для студентів вищих навчальних закладів. Київ : ВЦ «Академія», 2004. $336 \mathrm{c}$.

\section{REFERENCES}

1. Kubrjakova E.S.(1978) Chasti rechi v onomasiologicheskom osveshhenii [ Parts of Speech in Onomaseological Description ]. M.: Nauka, 115 pp. (in Russian).

2. Zahnitko A.P. (1996) Teoretychna hramatyka ukrainskoi movy: Morfolohii [Theoretical Grammar of the Ukrainian Language. Morphology]. Donetsk: DonDU, 437 pp. (in Ukrainian).

3. Kolesnykov A.O.(2000) Syntahmatychna paradyhmatyka katehorii chysla morfolohichno nedostatnikh imennykiv [ Syntagmatic Paradigm of Category of Number of Morphologically Insufficient Nouns] (PhD Thesis), Odesa : I. Mechnikov National Medical University.

4. Vykhovanet I.R.(2004) Teoretychna morfolohiia ukrainskoi movy: Akadem. hramatyka ukr. movy [Theoretical Morphology of the Ukrainian Language]. K.: «Pulsary», 400 pp. (in Ukrainian).

5. Halkyna-Fedoruk E.M.(1957) $O$ forme $i$ soderzhanii v jazyke [About Form and Content in the Language] . M.: State Publisher of Political Literature, pp. 352-407 (in Russian).
6. Myloslavskyi Y.H.(1981) Morfologicheskie kategorii sovremennogo russkogo jazyka [ Morphological Categories of Modern Russian Language]. M.: Prosveshhenie, 254 pp. (in Russian).

7. Rusanivskyi V.M., Taranenko O.O. (2000) Ukrainska mova: Entsyklopediia [Ukrainian Language.Encyclopedia]. K.: Ukr. entsykl., 752 pp. (in Ukrainian).

8. Ozhohan V.M.(1997) Zaimennykovi slova u hramatychnii strukturi suchasnoi ukrainskoi movy [Pronoun words in Grammar Structure of Modern Ukrainian Language]. K., 230 pp. (in Ukrainian).

9. Matviias I.H. (1962) Syntaksys zaimennykiv $v$ ukrainskii movi [ Syntax of Pronouns in the Ukrainian Language]. K.: AN URSR, 131 pp. (in Ukrainian).

10. Leonova M.V.(1983) Suchasna ukrainska literaturna mova. Morfolohiia [ Modern Ukrainian Literature Language. Morphology]. K.: Vyshcha shk., 264 pp. (in Ukrainian).

11. Rusanovskij V.M., Zhovtobrjuh M.A. Gorodenskaja E.G., Grishhenko A.A. (1986) Ukrainskaja grammatika [Ukrainian Grammar]. K.: Nauk. dumka (in Russian).

12. Rudenko D.Y.(1990) Kategorija imeni vosnovnyh paradigmah «filosofii jazyka» [Category of Noun in Major Paradigms of Language Philosophy] (PhD Thesis) M.: Institute of Linguistics. 63 pp.

13. Superanskaja A.V.(1978) Apelljativ - onoma [Appellative - onoma ]. M.: Nauka, pp. 5-34 (in Russian).

14. Mospan O.P.(2000) Pole zbirnykh imennykiv u rosiiskii movi: osoblyvosti semantyky ta prahmatyky [ Field of Collective Nouns in the Russian language: Peculiarities of Semantics and Pragmatics] (PhD Thesis) Kh.: V. Karazin Kharkiv National University.

15. Horpynych V.O. (2004) Morfolohiia ukrainskoi movy[Morphology of the Ukrainian Language]. K.: Akademiia, 336 pp. (in Ukrainian). 